


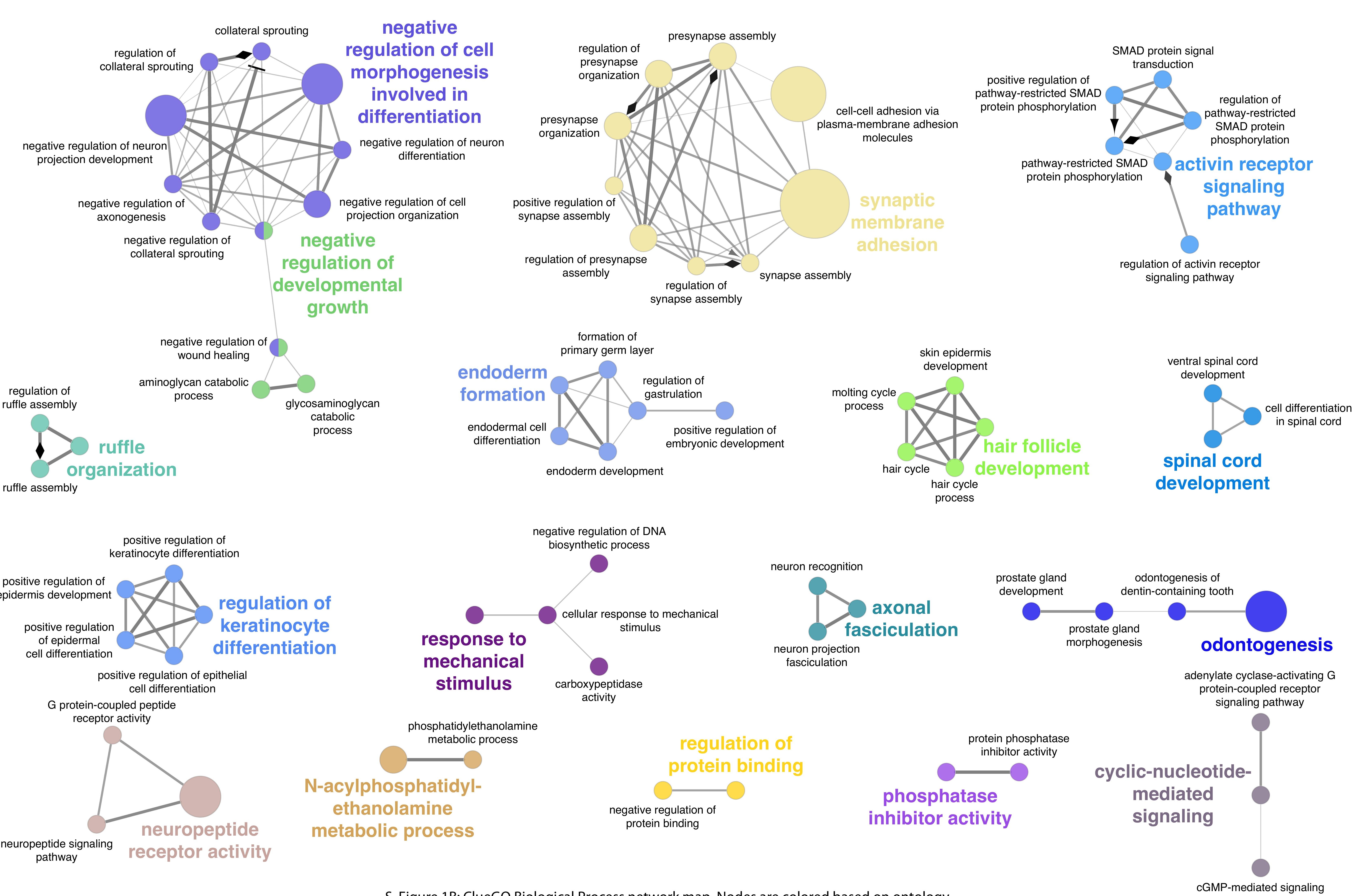

S. Figure 1B: ClueGO Biological Process network map. Nodes are colored based on ontology and node size indicates signi icance (all P values $<0.05$ ). 
protein tyrosine

phosphatase

activity

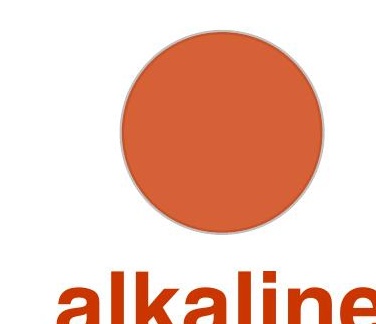

hosphatase activity

regulation of

superoxide

metabolic

process

smooth muscle

cell differentiation regulation of

endothelial cell

apoptotic

process aromatic amino

acid family

catabolic

process

cell-cell adhesion

mediator activity

\section{cell adhesion} mediator activity

response to zinc ion

extracellular

\section{signaling cascade

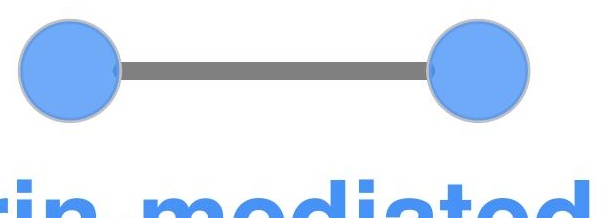 \\ signaling \\ calcineurin-mediated}

calcineurin-NFAT

potassium ion transmembrane transporter activity

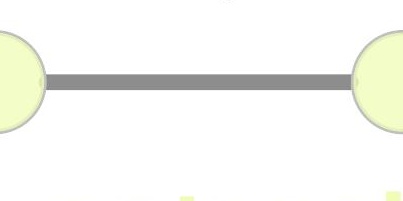

ootassium io

ransport cellular component assembly involved in morphogenesis

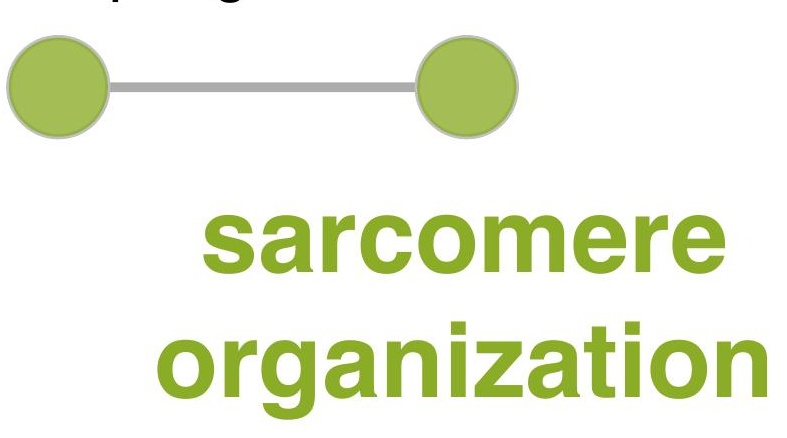

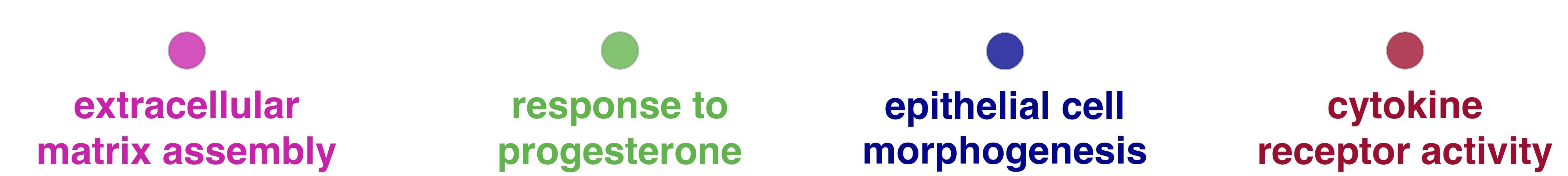
matrix assembly

sensory

perception of

taste negative

regulation of

synaptic

transmission positive regulation of

dendrite development regulation of

myotube

differentiation regulation of

neuron

migration 

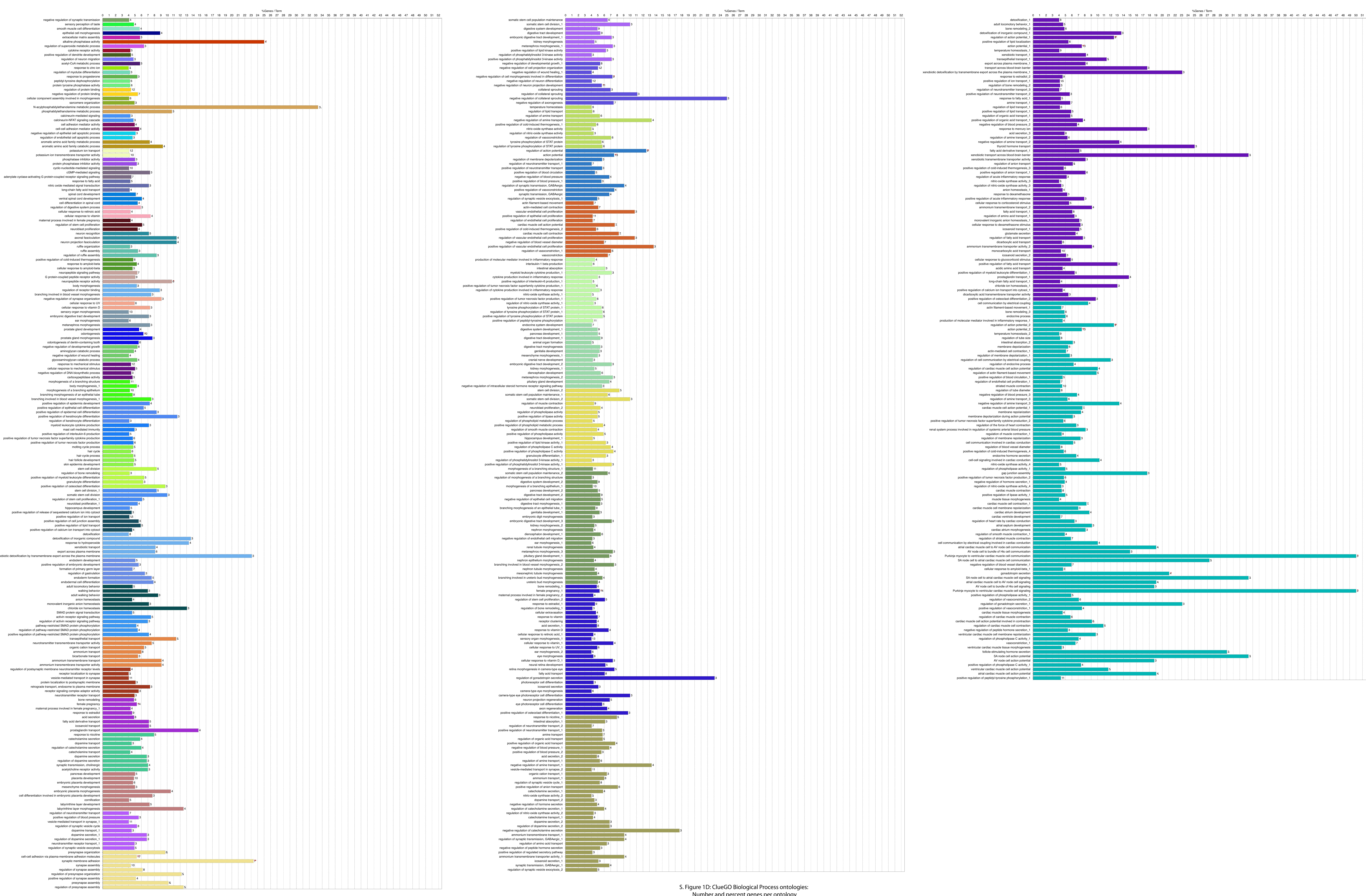


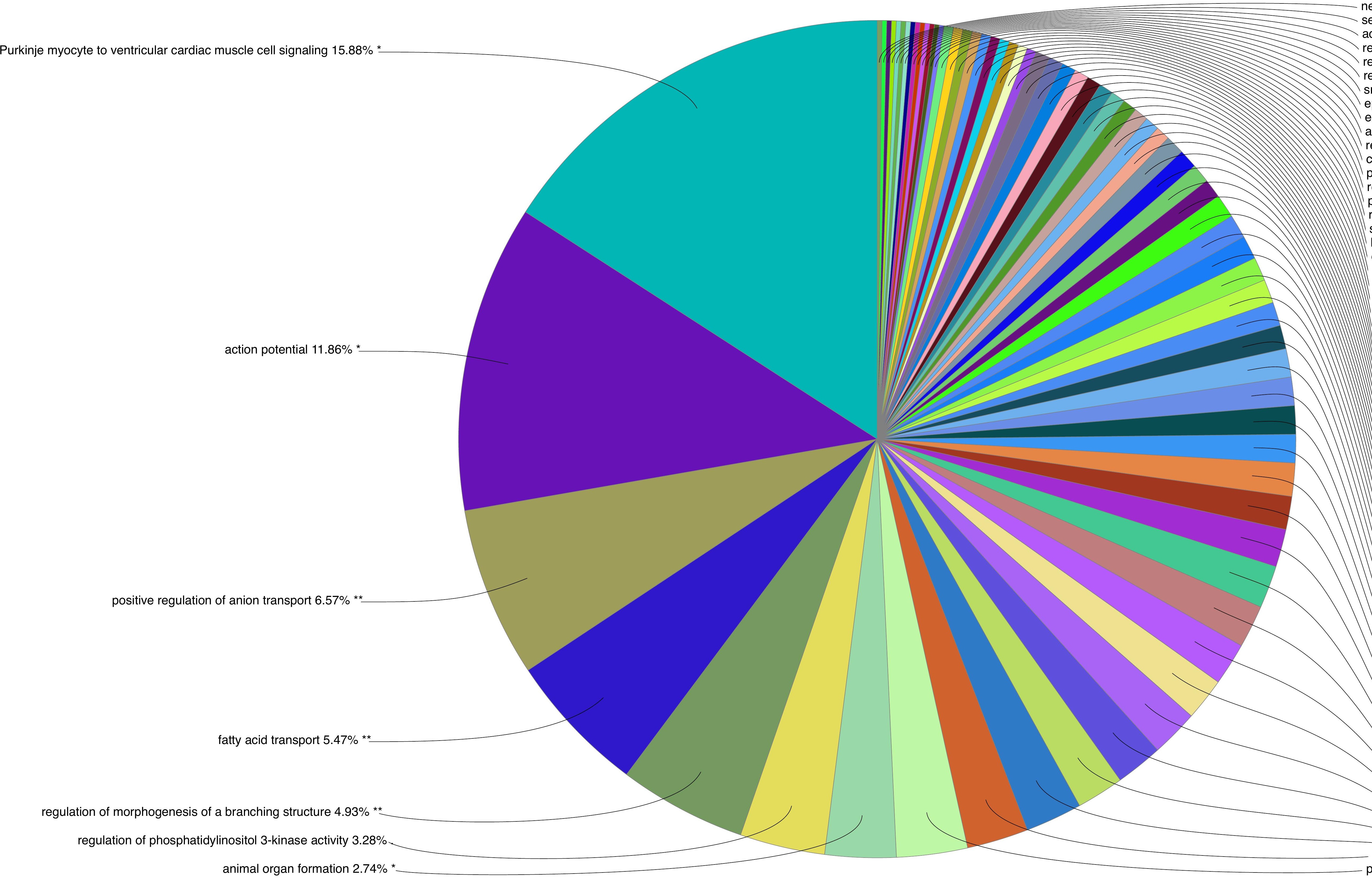

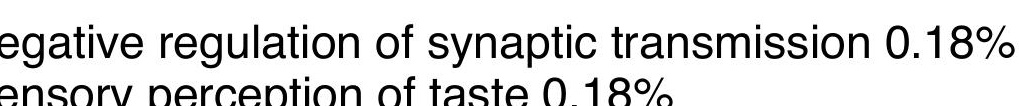
acetyl-CoA metabolic process 0.18\%

response to zinc ion $0.18 \%$.

egulation of myotube differentiation $0.18 \%$

smooth muscle cell differentiation $0.18 \%$

epithelial cell morphogenesis $0.18 \%$

alkaline phosphatase activity $0.18 \%$ *

regulation of superoxide metabolic process $0.18 \%$

cytokine receptor activity $0.18 \%$

政

protein tyrosine phosphatase activity $0.36 \%$

egulation of protein binding $0.36 \%$

$\mathrm{N}$-acylphosphatidylethanolamine metabolic process $0.36 \%$

calcineurin-mediated signaling $0.36 \%$
cell adhesion mediator activity $0.36 \%$

cell adhesion mediator activity $0.36 \%$
regulation of endothelial cell apopototic process $0.36 \%$

aromatic amino acid family catabolic process $0.36 \%$

potassium ion transport $0.36 \%$.
phosphatase inhibitor activity $0.36 \%$

phosphatase inhibitor activity 0.36\%
cyclic-nucleotide-mediated signaling $0.55 \%$
nitric oxide mediated signal transduction $0.55 \%$

spinal cord development $0.55 \%$

cellular response to vitamin $0.55 \%$
regulation of stem cell proliferation $0.55 \%$

axonal fasciculation $0.55 \%$

ruffle organization $0.55 \%$
cellular response to amyloid-beta $0.55 \%$

neuropeptide receptor activity $0.55 \%$

anching involved in blood vessel mo

cellular response to UV $0.55 \%$
sensory organ morphogenesis $0.73 \%$
odontogenesis $0.73 \%^{* *}$

negative regulation of developmental growth $0.73 \%$

response to mechanical stimulus $0.73 \%$

regulation of keratinocyte differentiation $0.91 \%$

mast cell mediated immunity $0.91 \%$
hair follicle development $0.91 \%$

hair follicle development $0.91 \%$
stem cell division $0.91 \%$

neuroblast proliferation $0.91 \%$

positive regulation of ion transport $0.91 \%$

export across plasma membran 1

endoderm formation $1.09 \%$
chloride ion homeostasis $1.09 \%$

activin receptor signaling pathway $1.09 \%$

receptor localization to $1.28 \%$

female pregnancy $1.46 \%$
response to nicotine $1.64 \%$

regulation of synaptic vesicte cyct $1.64 \%$

synaptic membrane adhesion $1.64 \%$ **

digestive tract development $1.82 \%$.

(1.82\% regulation of action potential $2.19 \%$ *

animal organ fo

S. Figure 1E: ClueGO Biological Process ontologies, percent representation: Colors represent ontology groups. 


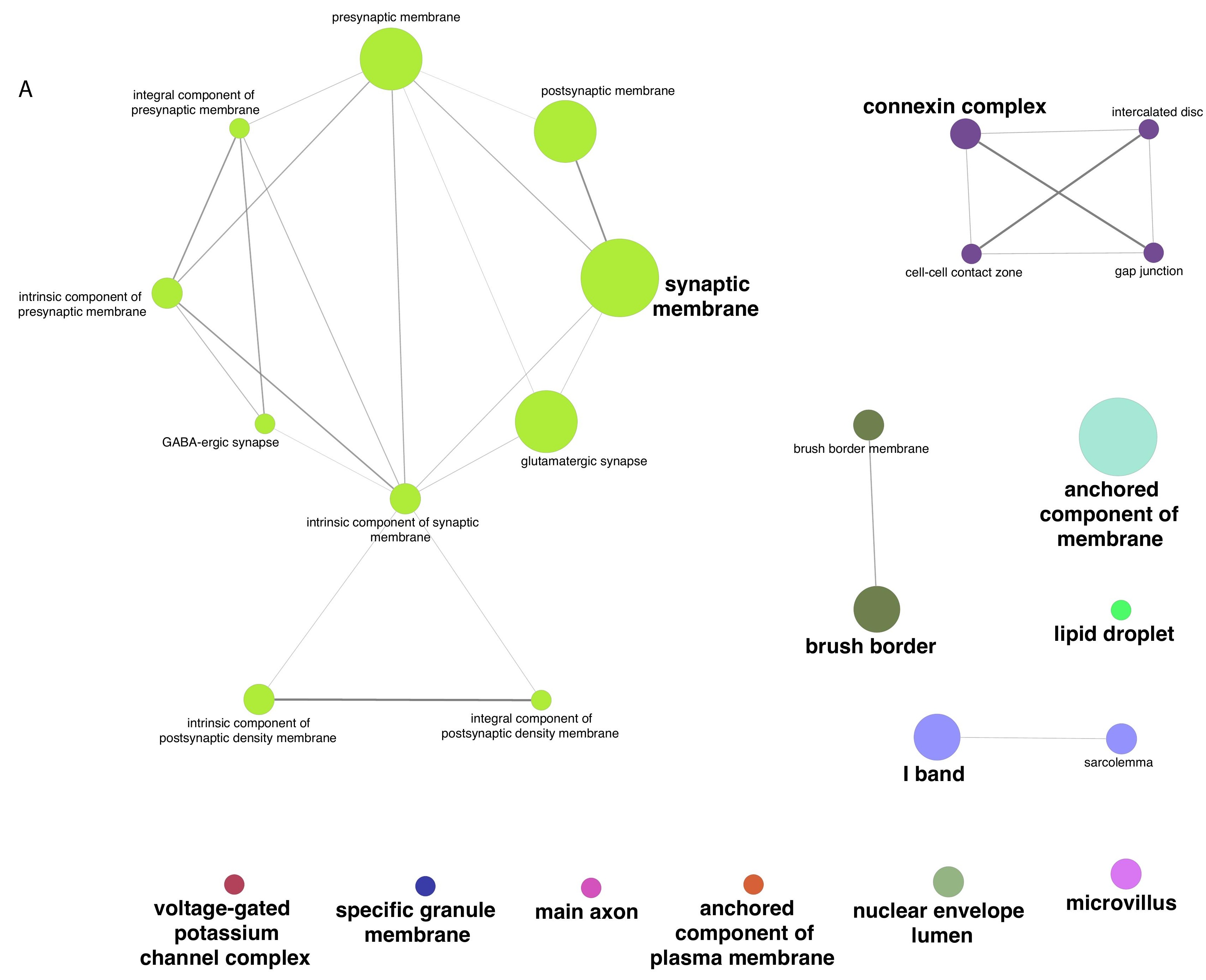

S. Figure 2A: ClueGO Cellular Component network map. Nodes are colored based on ontology and node size indicates significance (all P values $<0.05$ ). 


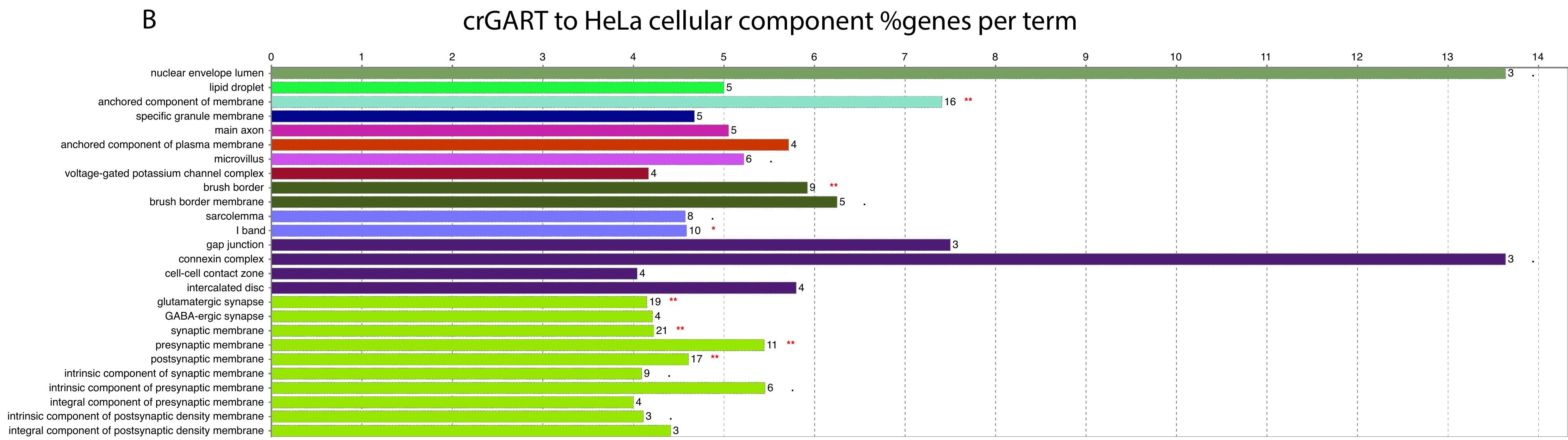

C

crGART to HeLa cellular component terms per group

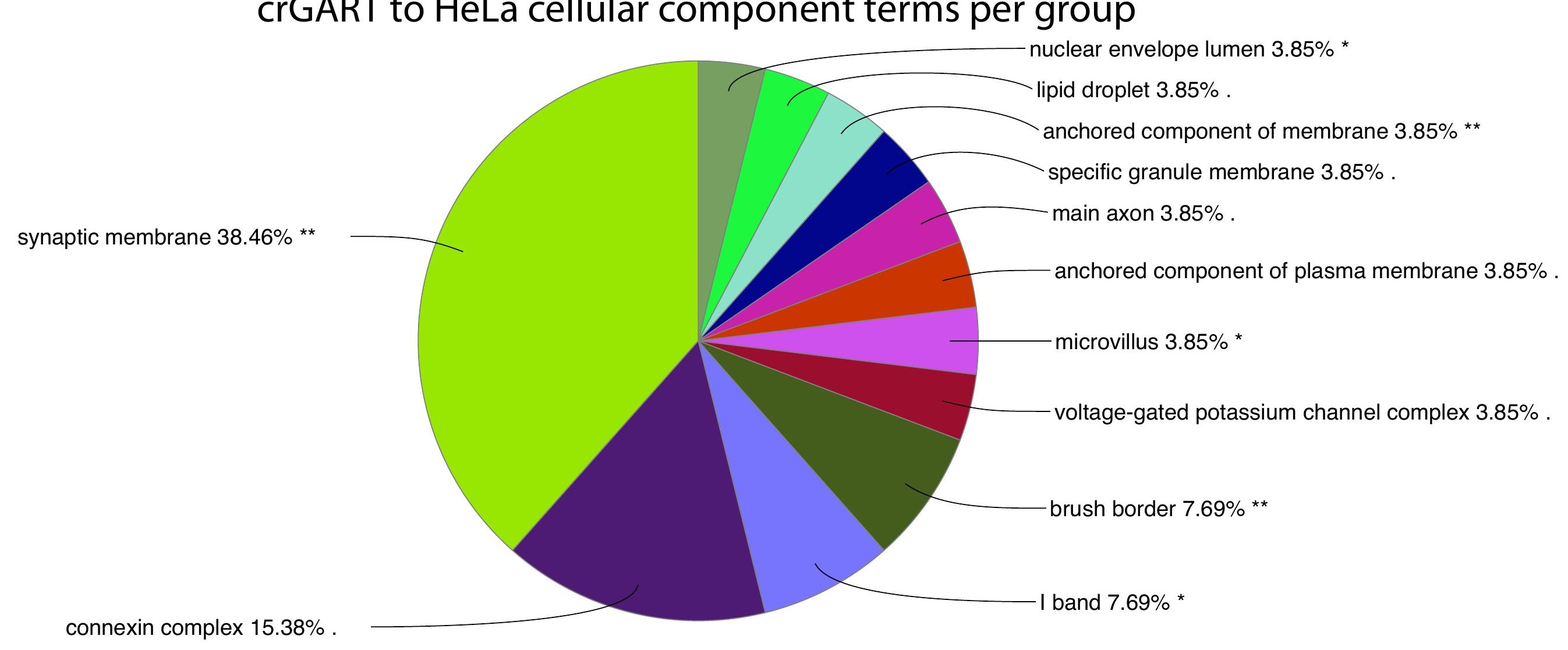

S. Figure 2: B) ClueGO Cellular Component ontologies: Number and percent genes per ontology C) Percent representation: Colors represent ontology groups. 
A
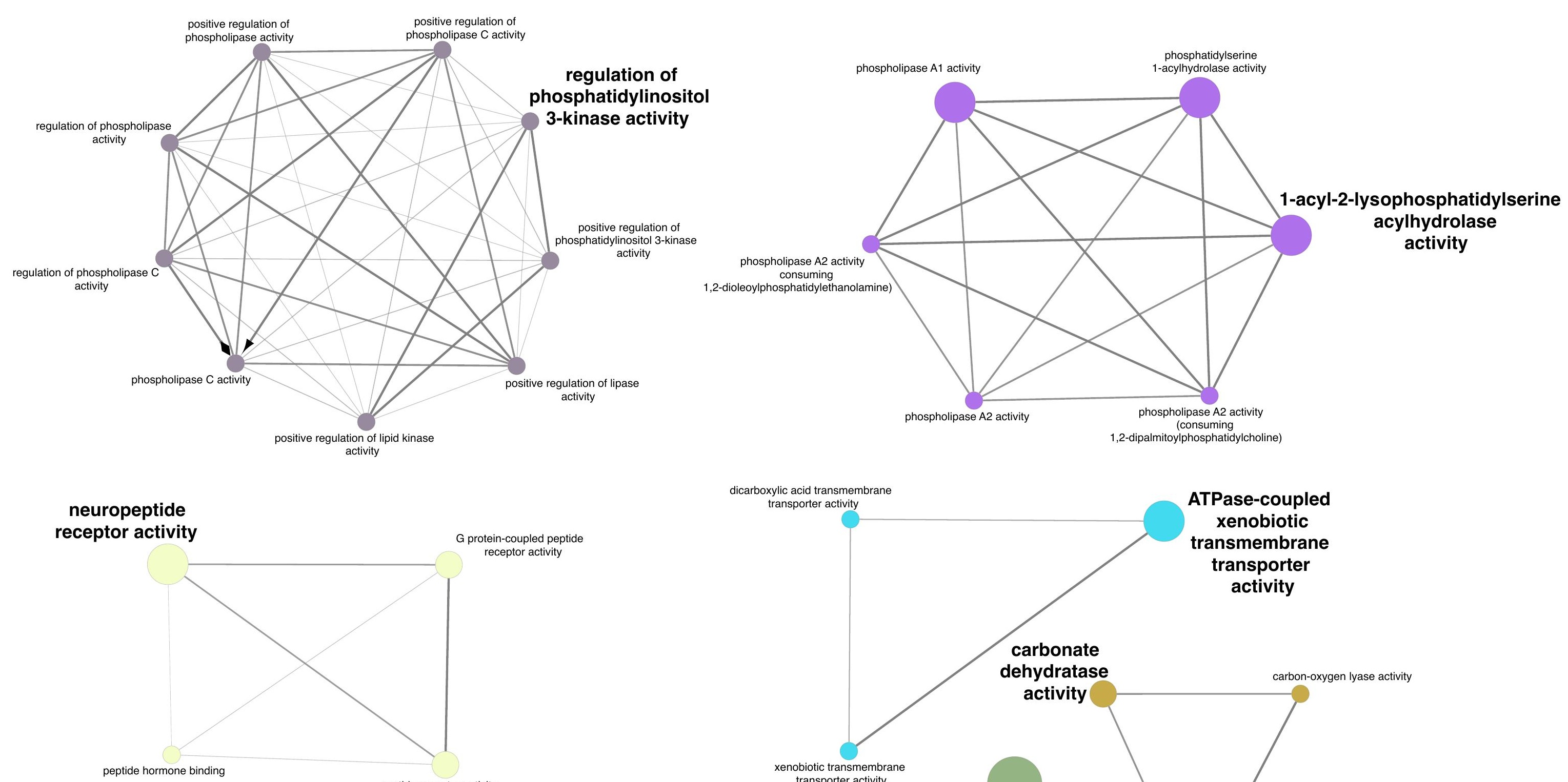

xenobiotic

transmembrane

transporter
activity

peptide hormone bind

pepitide receptor activin
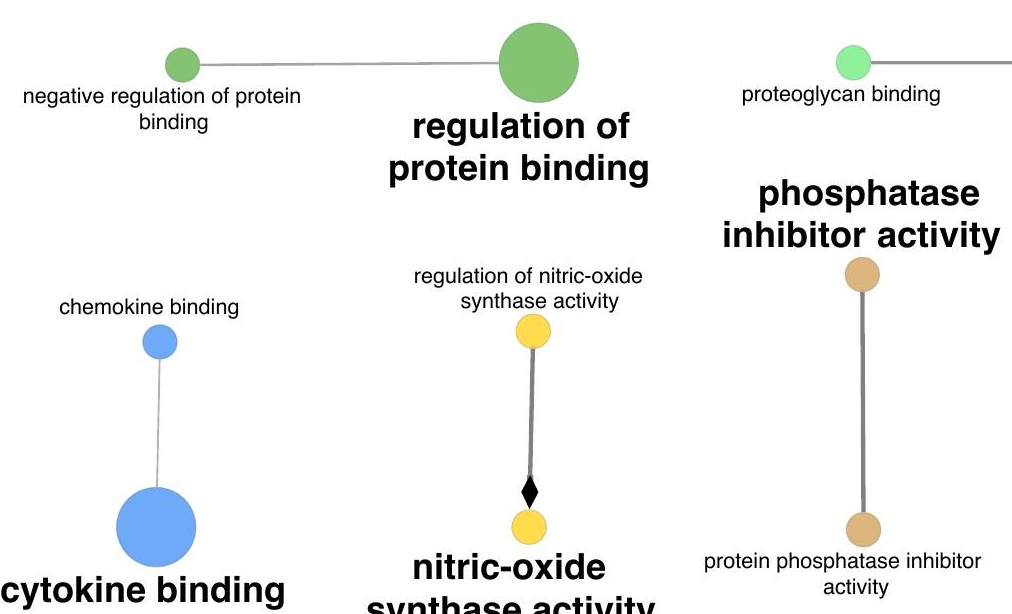

syndecan binding

protein binding
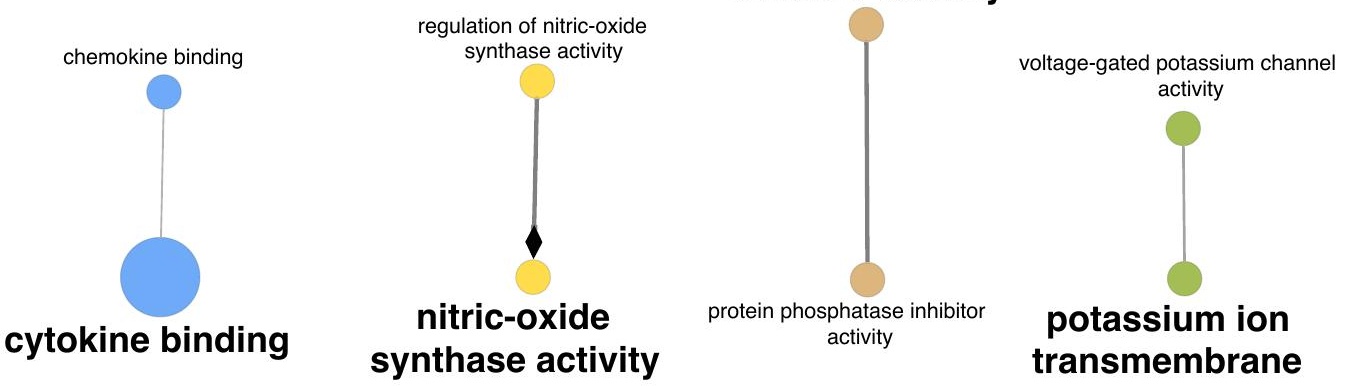

ransporter

activity

potassium ion

transmembrane

transporter
activity
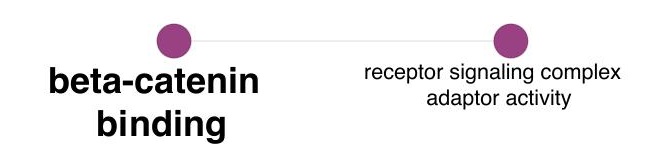

carboxypeptidase
activity

PDZ domain
binding

nitric-oxide

synthase binding

regulation of
receptor binding

cytokine receptor
activity

protein tyrosine
phosphatase

coreceptor activity

activity

receptor
serine/threonine

kinase binding

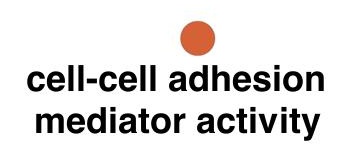

mediator activity

S. Figure 3A: ClueGO Molecular Function network map. Nodes are colored based on ontology and node size indicates significance (all $\mathrm{P}$ values $<0.05$ ). 


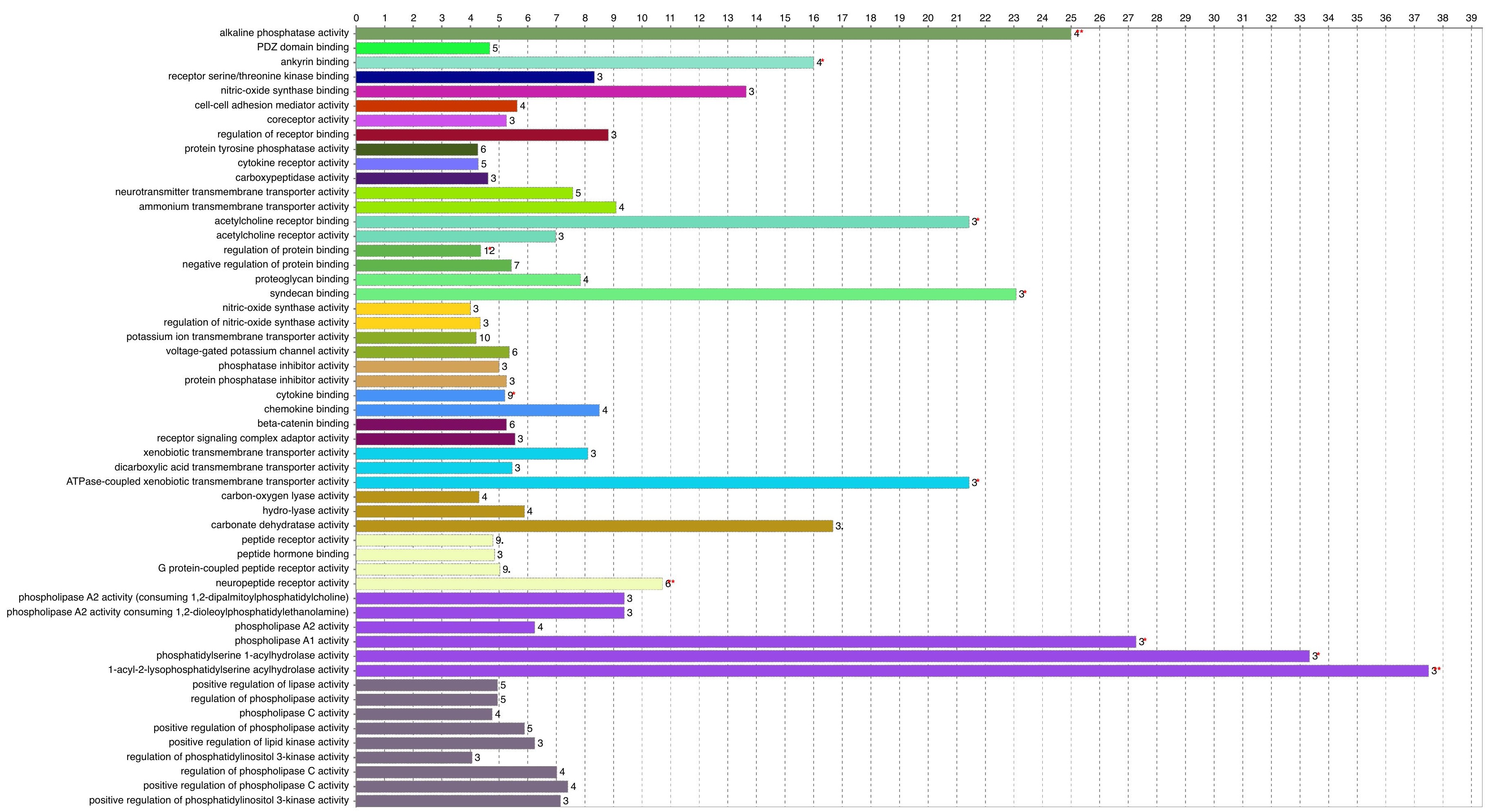

\section{crGART to HeLa molecular function terms per group}

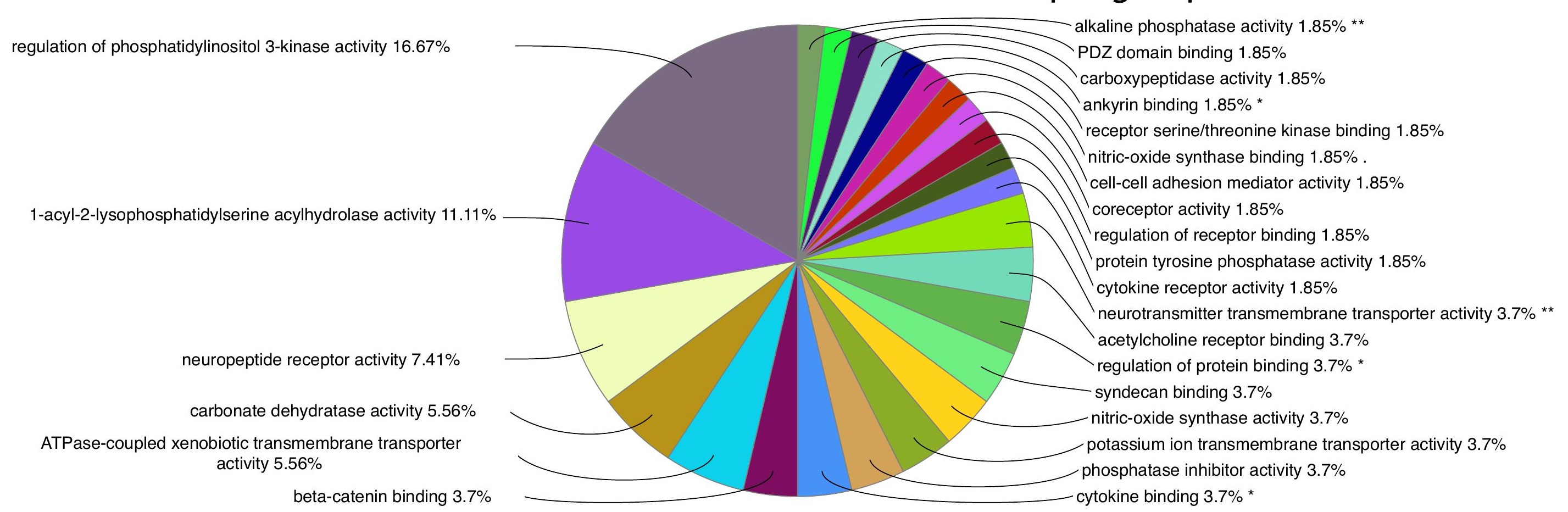

S. Figure 3: B) Molecular Function ontologies: Number and percent genes per ontology C) Percent representation: Colors represent ontology groups. 
A
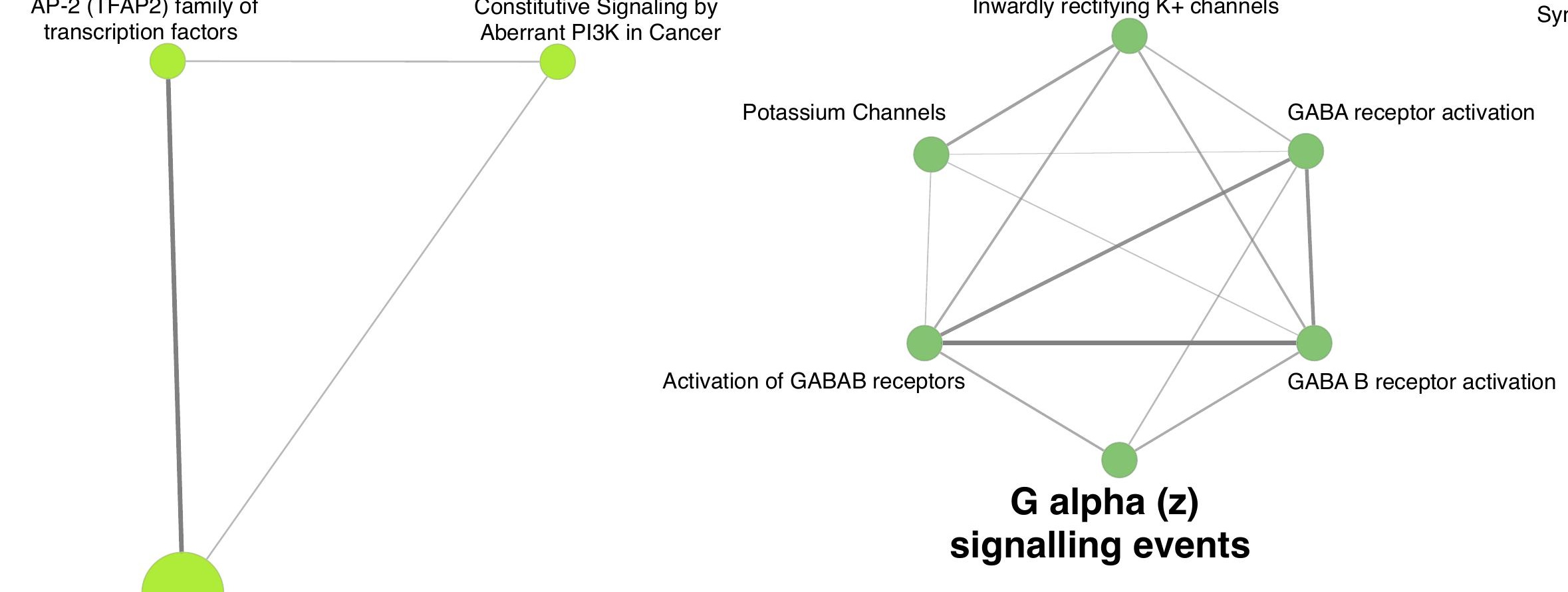

TFAP2 (AP-2)

family regulates transcription of

growth factors

and their

receptors

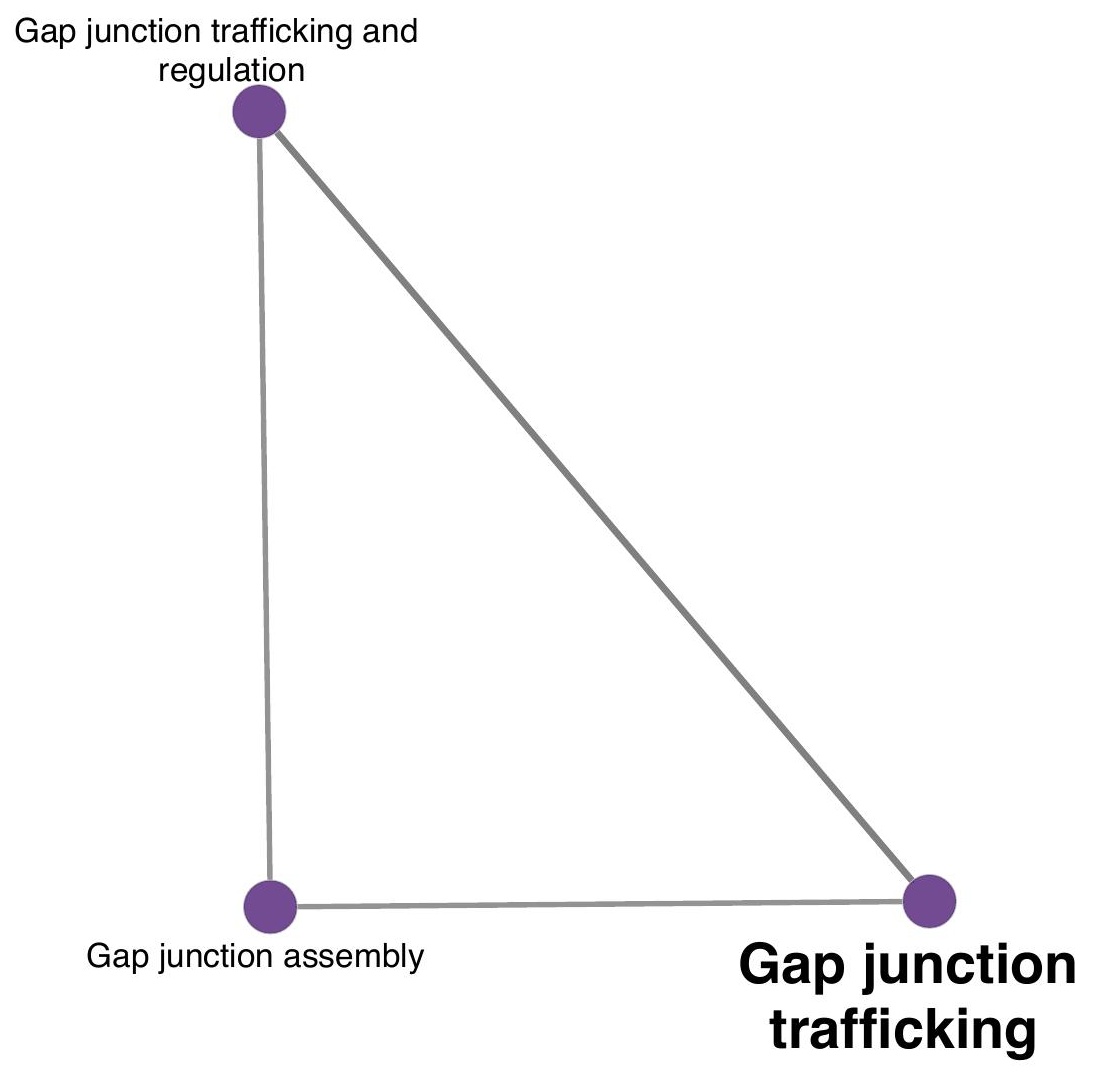

Cell surface

interactions at the

vascular wall

trafficking

\section{G alpha (z)}

signalling events

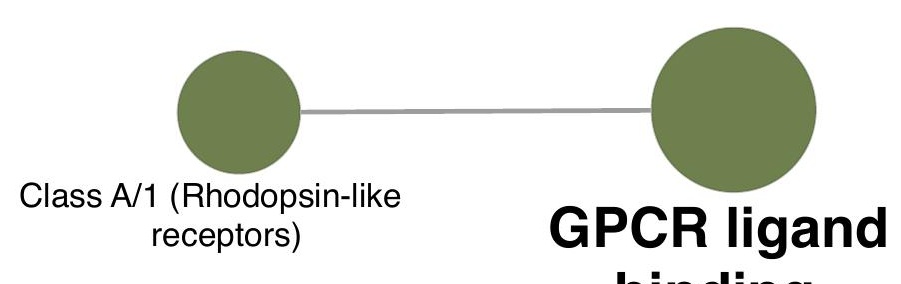

binding

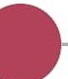
Peptide hormone metabolism Incretin synthesis, secretion, and
inactivation

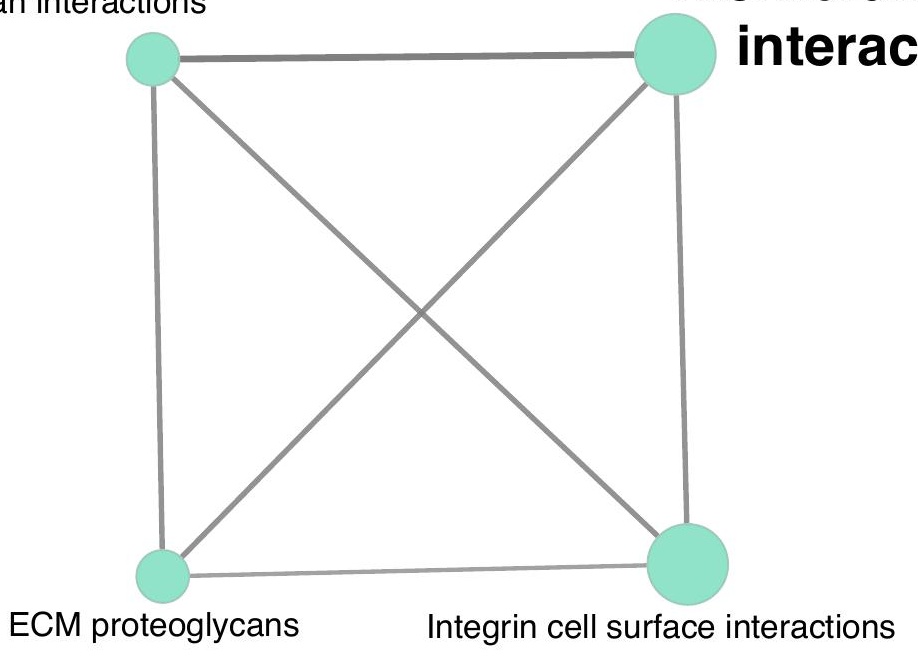

ECM proteoglycans

Integrin cell surface interactions

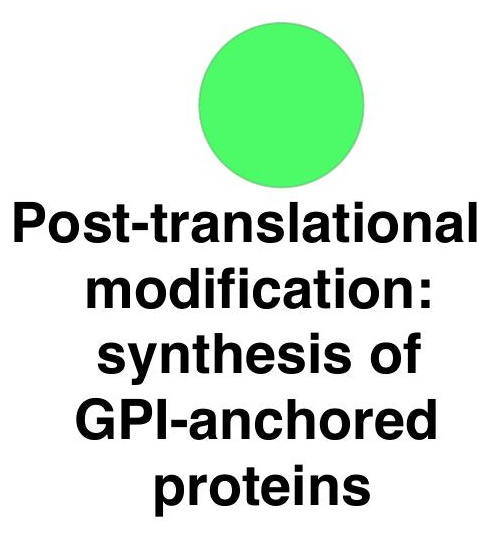

Acyl chain remodelling of $P E$

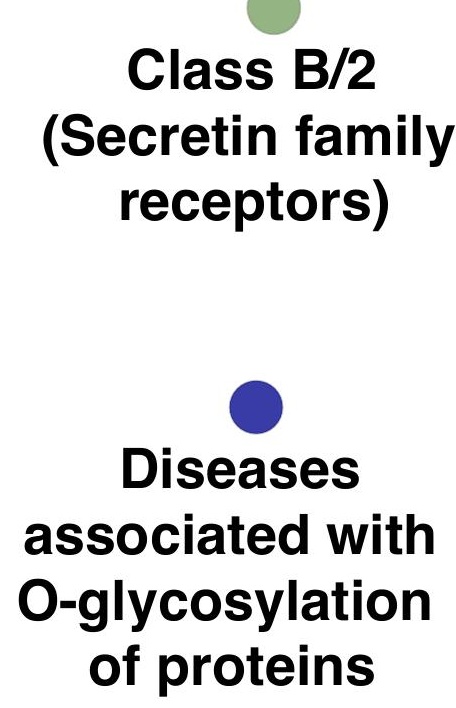

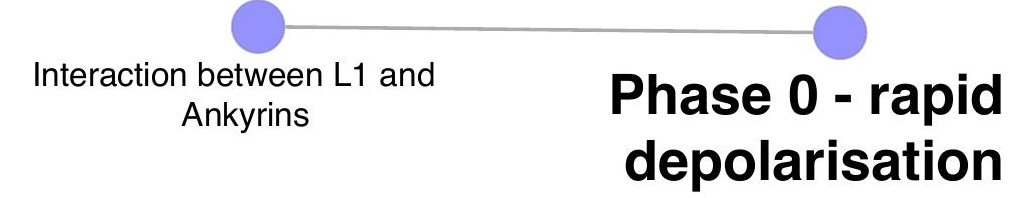
G alpha (12/13)
signalling events
Transport of

inorganic

cations/anions

and amino

acids/oligopeptides

S. Figure 4A: ClueGO Reactome Pathways network map. Nodes are colored based on pathway and node size indicates significance (all P values $<0.05)$. 
crGART to HeLa Reactome pathways \%genes per term

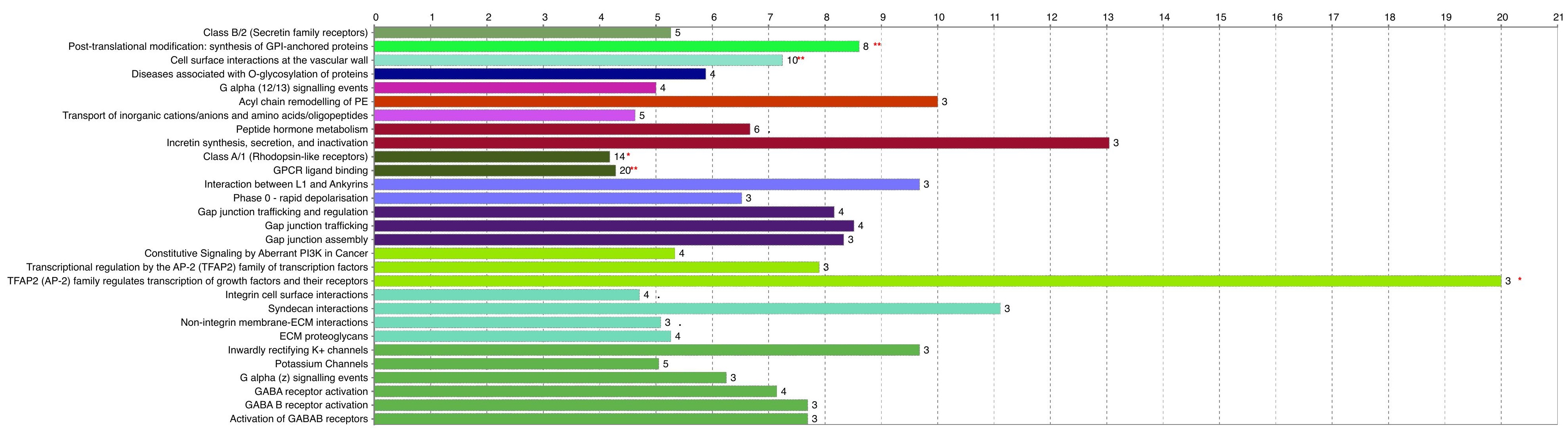

C

crGART to HeLa Reactome pathways terms per group

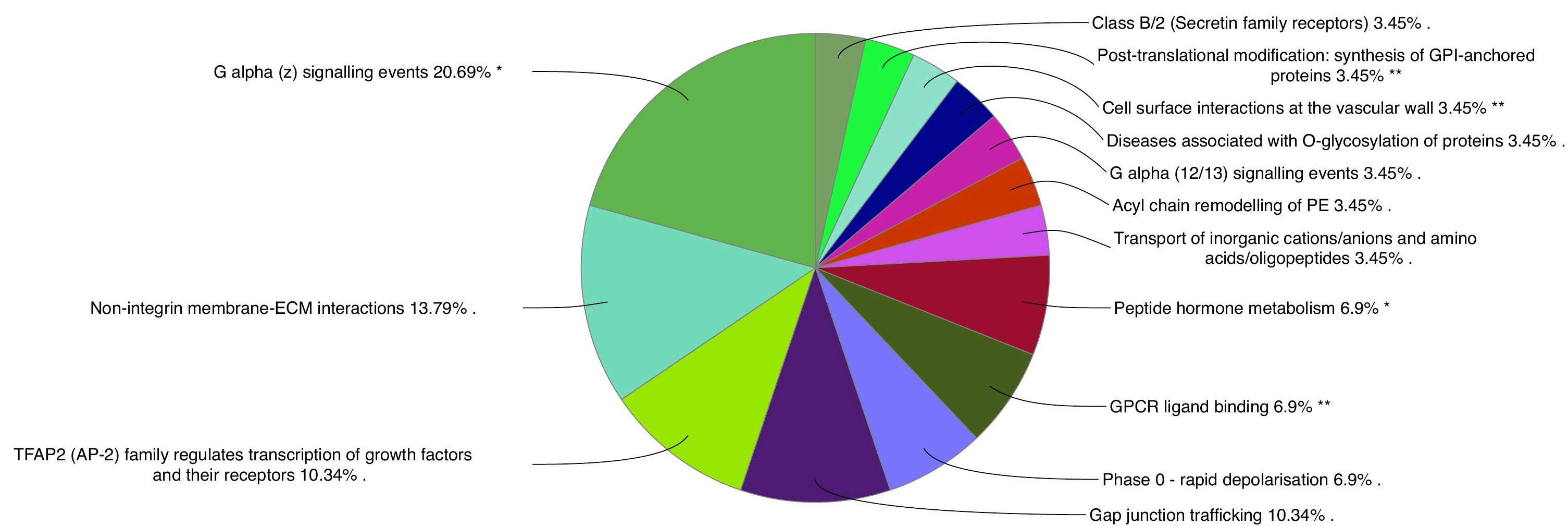

S. Figure 4: B) Reactome Pathways: Number and percent genes per pathway C) Percent representation: Colors represent pathway groups. 

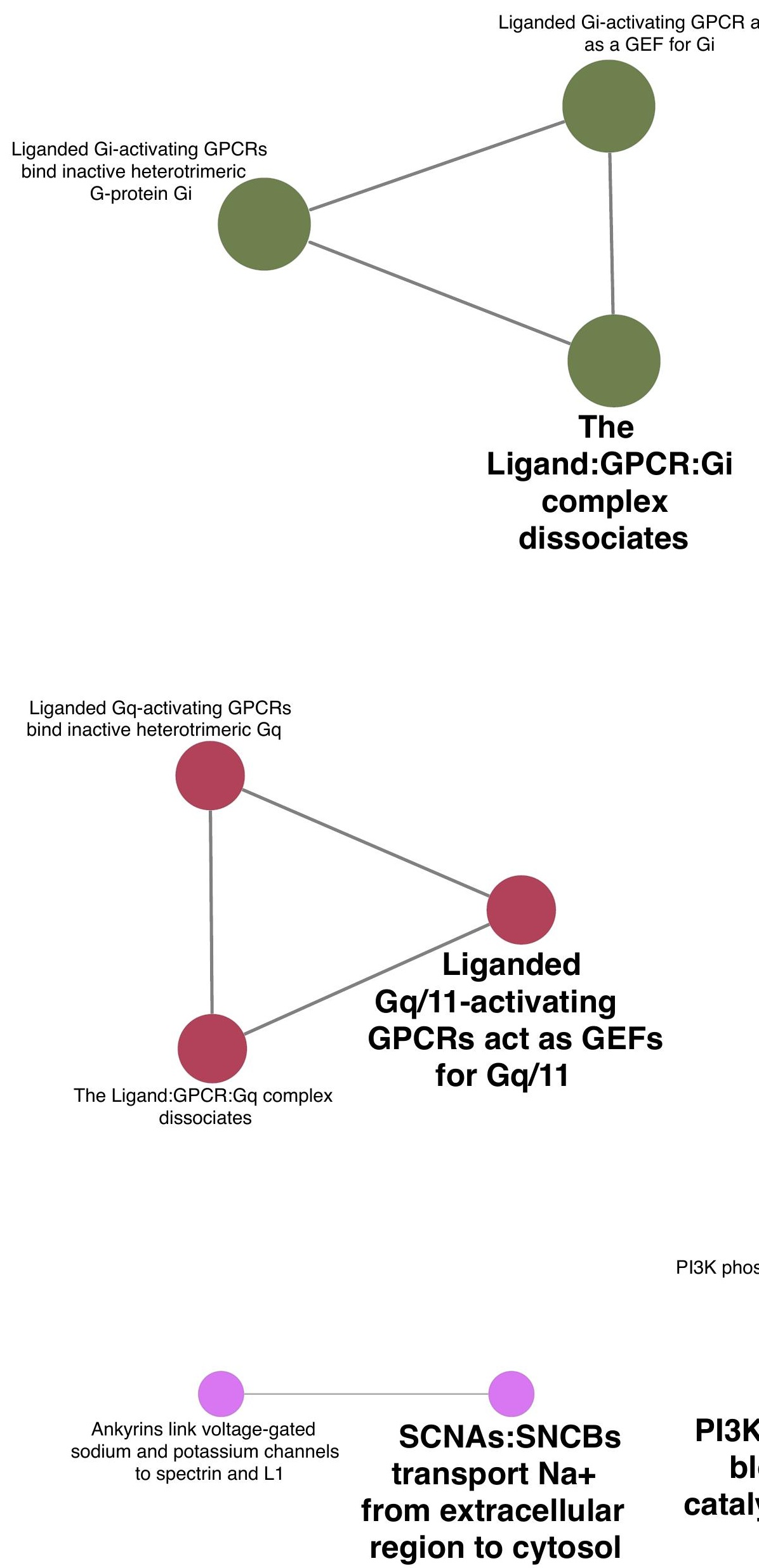

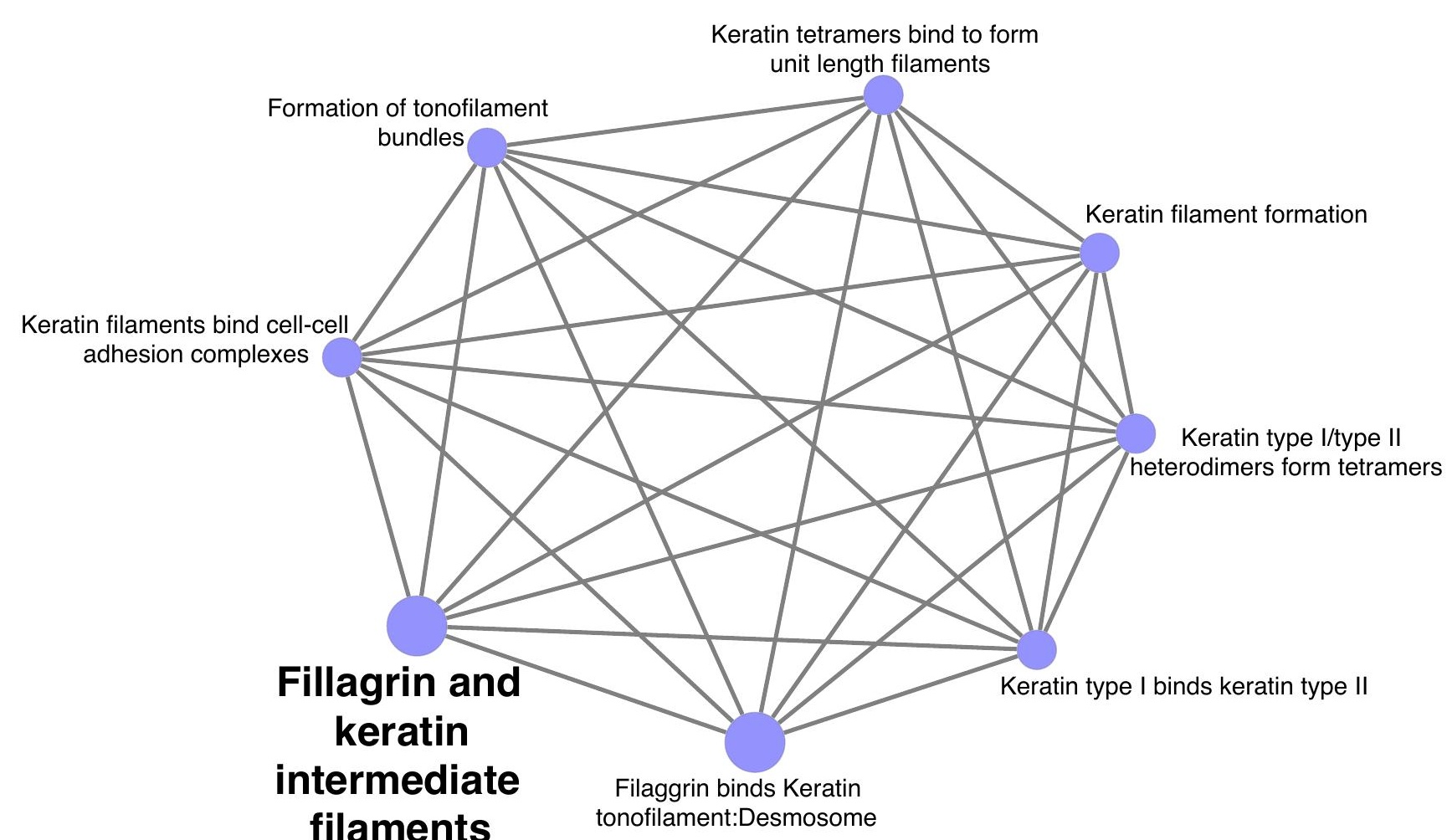

filaments

polymerise

forming a network
PSGs bind

TGF-beta1 proteoglycans and
GPLD1 hydrolyses

proteins
GPI-anchors from
HRASLS transfer

acyl group from

PC to PE to form

S. Figure 5A: ClueGO Reactome Reactions network map. Nodes are colored based on reaction and node size indicates significance (all P values $<0.05)$.

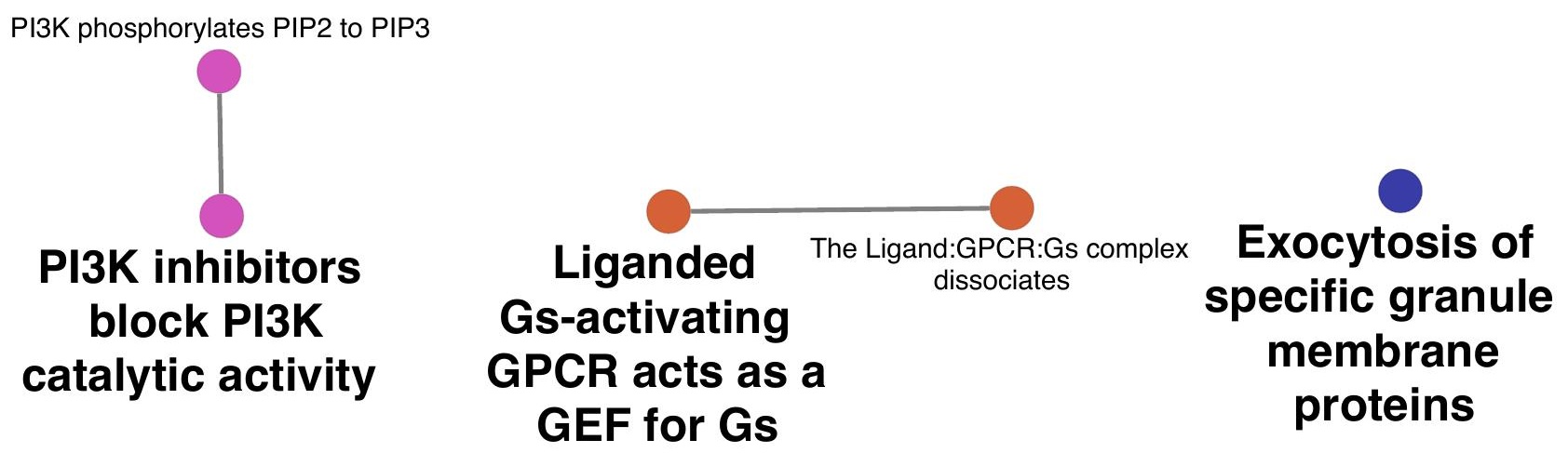


crGART to HeLa Reactome reactions \%genes per term

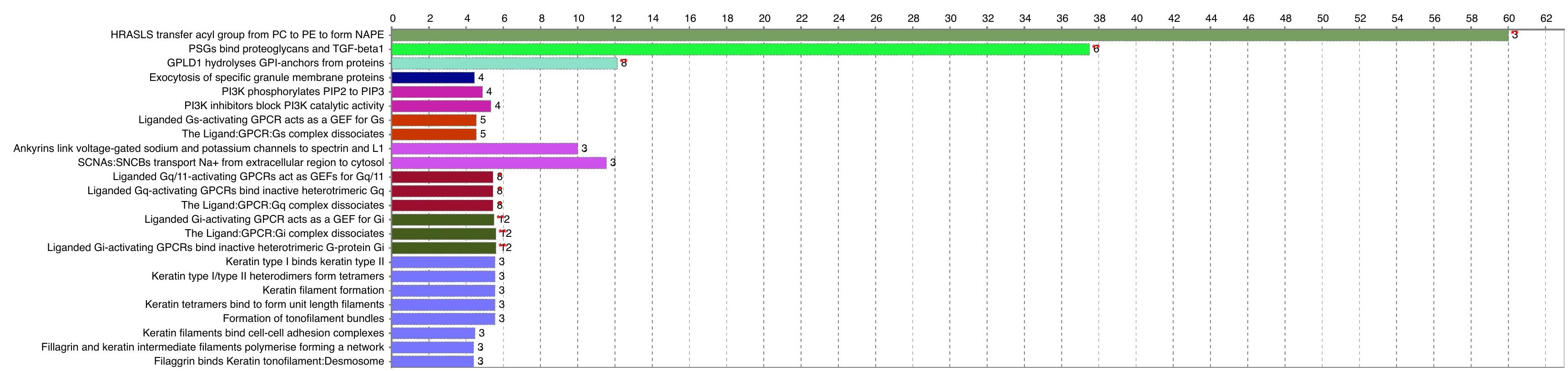

C

crGART to HeLa Reactome reactions terms per group

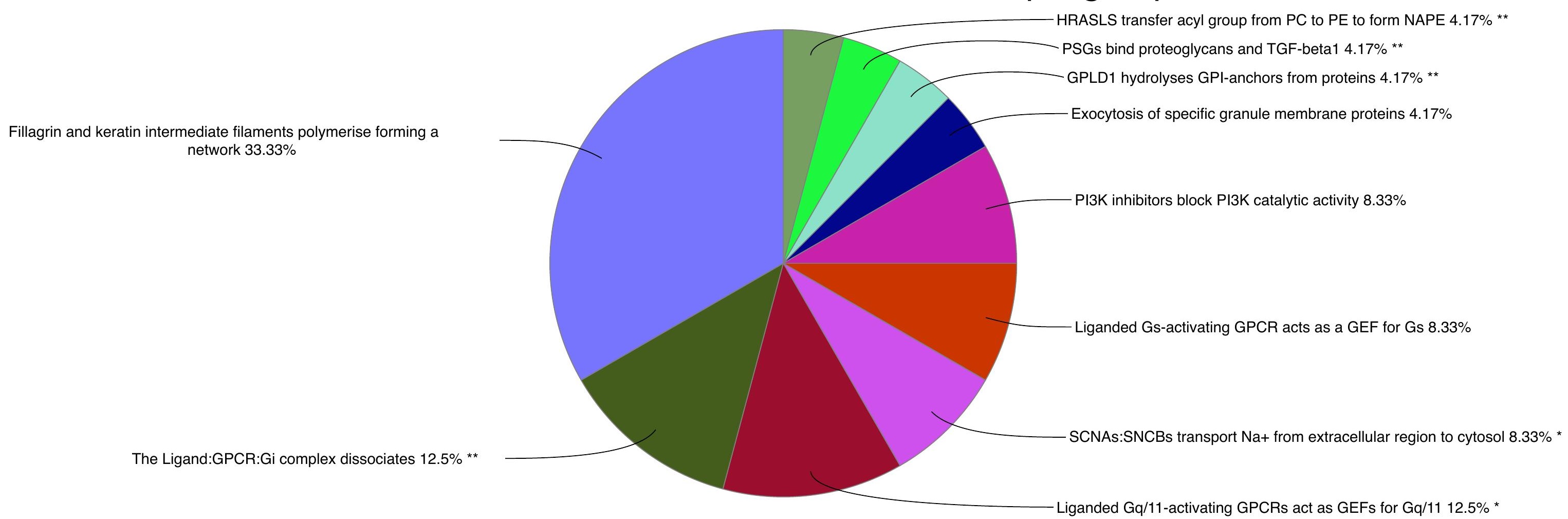

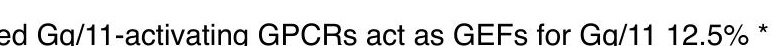

S. Figure 5: B) Reactome Reactions: Number and percent genes per reaction C) Percent representation: Colors represent reaction groups. 

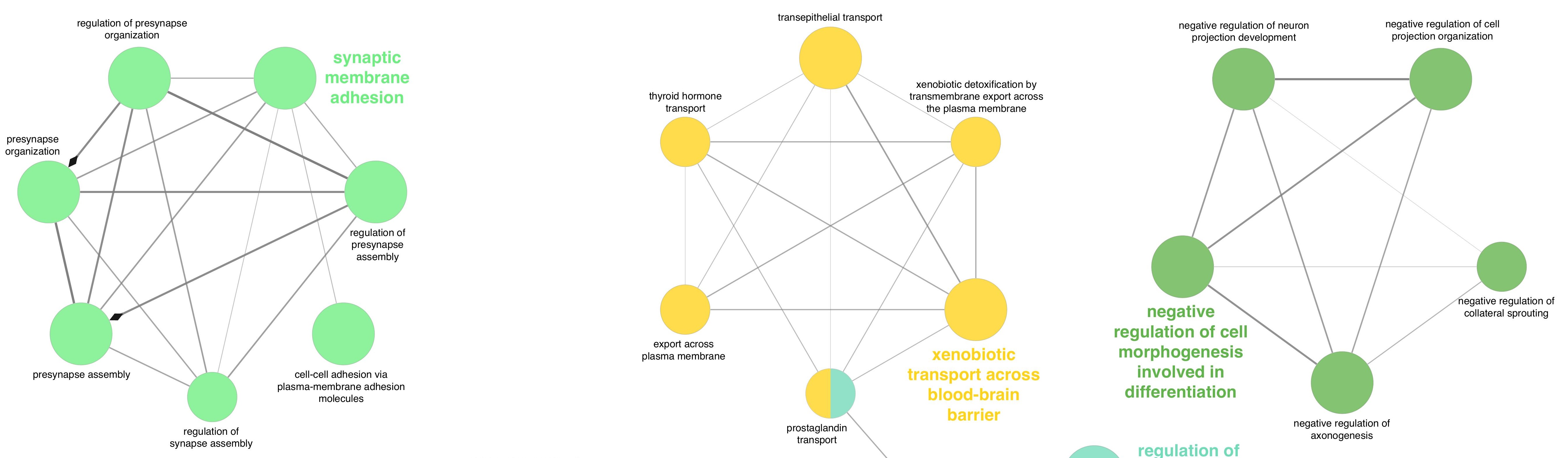
neuropeptide
receptor activity

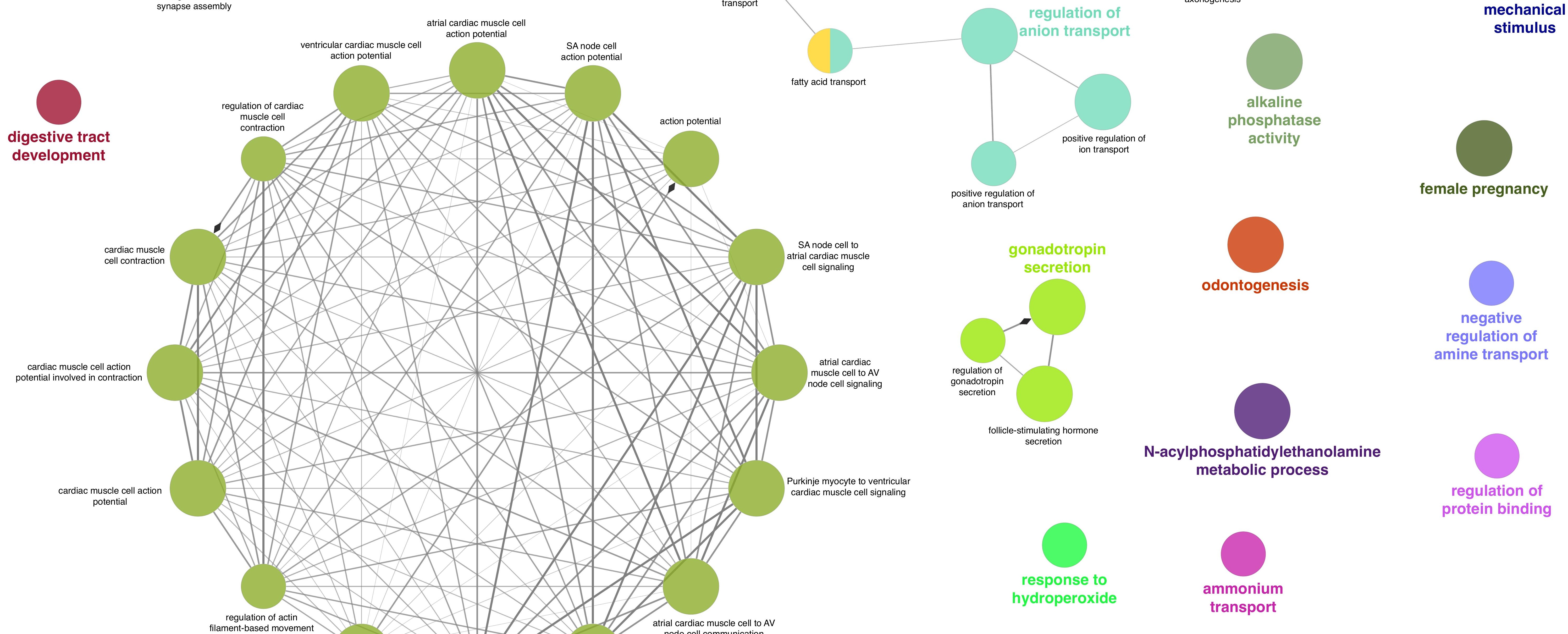




$$
\begin{array}{r}
\text { alkaline phosphatase activity } \\
\text { response to hydroperoxide } \\
\text { neuropeptide receptor activity } \\
\text { response to mechanical stimulus } \\
\text { ammonium transport } \\
\text { odontogenesis } \\
\text { regulation of protein binding } \\
\text { digestive tract development } \\
\text { female pregnancy }
\end{array}
$$

xenobiotic detoxification by transmembrane export across the plas... thyroid hormone transport across blood-brain barrier fatty acid transport_ 1 prostaglandin transport_1 regulation of action potential
action potential action potential of actin filament-based movement cardiac muscle cell action potential atrial cardiac muscle cell to AV node cell communication Purkinje myocyte to ventricular cardiac muscle cell communication

SA node cell to atrial cardiac muscle cell communication

SA node cell to atrial cardiac muscle cell signaling atrial cardiac muscle cell to AV node cell signaling Purkinje myocyte to ventricular cardiac muscle cell signaling cardiac muscle cell action potential involved in contraction regulation of cardiac muscle cell contraction
SA node cell action potential SA node cell action potential
ventricular cardiac muscle cell action potential atrial cardiac muscle cell action potentia
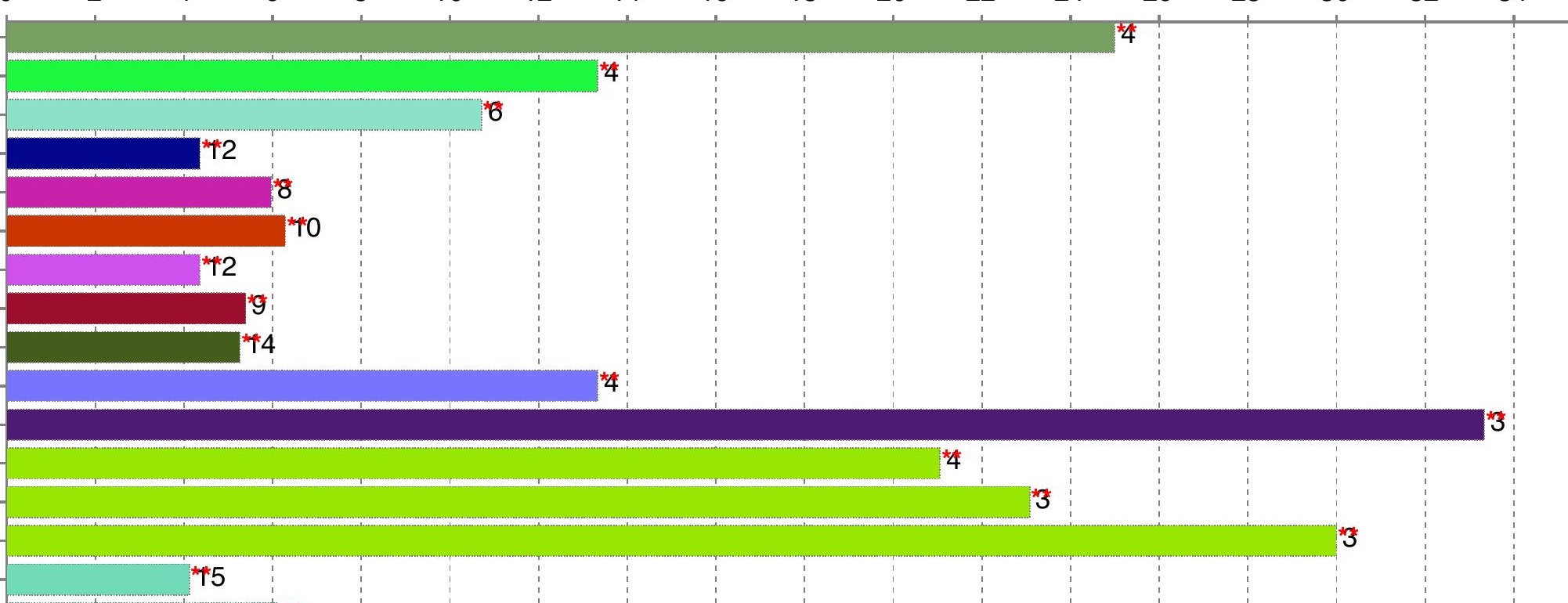

$+35$

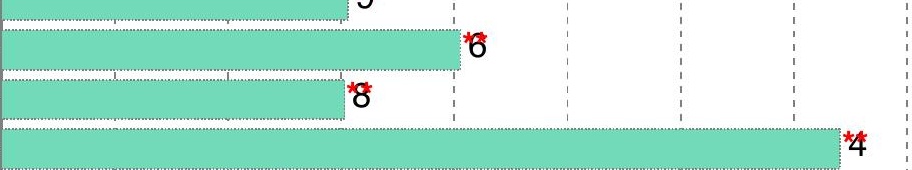

$+2$

$+1$
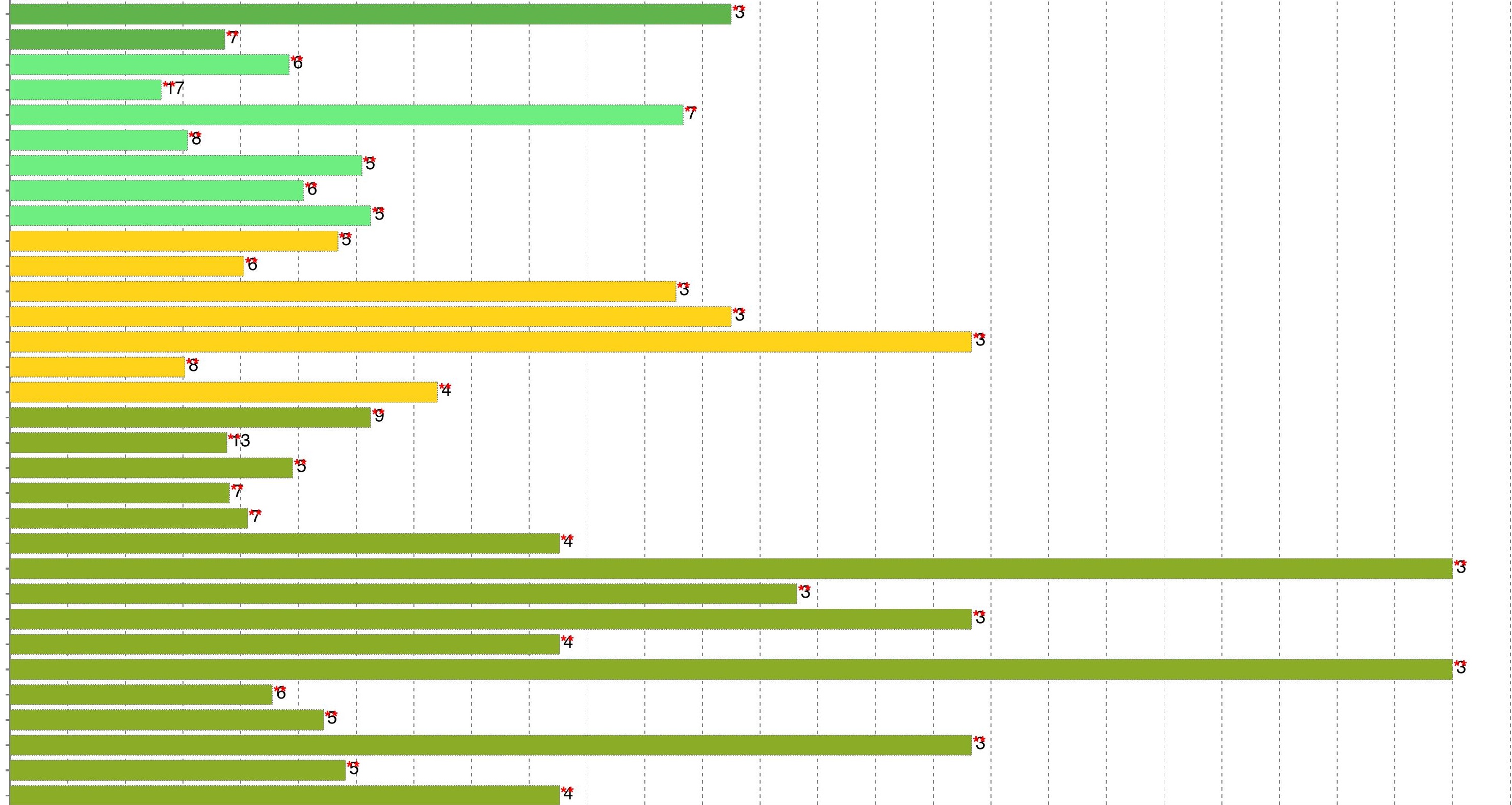

crGART to HeLa biological process terms per group

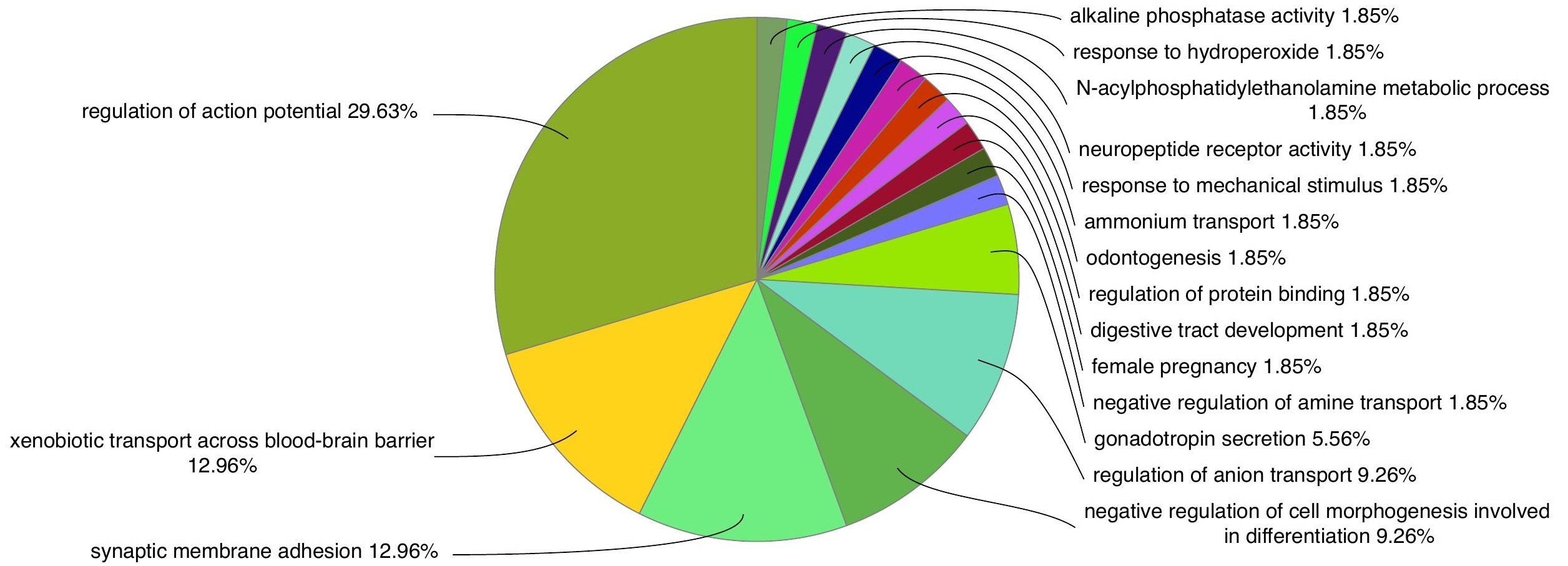

S. Figure 6: B) ClueGO Biological Process ontologies: Number and percent genes per ontology C) Percent representation: Colors represent ontology groups. 